\title{
Long Term Interactions of Microorganisms and Prudhoe Bay Crude Oil in Tundra Soils at Barrow, Alaska
}

\author{
ALAN SEXSTONE, PAULA GUSTIN and RONALD M. ATLAS
}

\begin{abstract}
Oil was recovered from tundra soils two and seven years after spillage. Oil persisted in the upper soil layer. The depth of penetration appears to depend on soil moisture and drainage characteristics. Maximal penetration seems to occur within one year of spillage. Biodegradation of the oil was indicated by changes in the ratio of gas chromatographically resolved to unresolved components. Individual components appear to be preferentially degraded, but no evidence was found for significant preferential degradation of structural classes of hydrocarbons. Numbers of microorganisms were different in oil contaminated and reference soils generally showing continued enrichment, but in some soils showing inhibition of microbial populations.
\end{abstract}

\begin{abstract}
RESUME. Du pétrole était récuperé des sols de toundras, deux et sept ans après son écoulement. Ce pétrole se conservait dans la partie supérieure du sol. La profondeur de pénétration parait dépendre du degré d'humidité du sol et des caractéristiques de drainage. La pénétration maximale semble avoir lieu un an après l'écoulement. Des changements dans les rapports de gaz, analysés au chromatographe, à ceux qui ne le sont pas, ont montré la biodégradation du pétrole. Certains composants apparaissent préférentiellement dégradés mais on ne trouvait aucune évidence à une dégradation préferentielle significative dans les "catégroies moléculaires" d'hydrocarbures. Dans les sols témoins, contaminés au pétrole, il y avait beaucoup de différence dans les micro-organismes - généralement il y avait un enrichissement continu mais dans certains sols, on observait des inhibitions de populations microbiennes.

Traduit par Alain de Vendigies, Aquitaine Co. of Canada Ltd.
\end{abstract}

\section{INTRODUCTION}

The transport of petroleum from the north slope of Alaska to the rest of the United States already has resulted in accidental spillages of hydrocarbons onto tundra soils. Future accidental petroleum contamination of tundra soils is likely. As part of a comprehensive study on the effects of oil on the belowground tundra ecosystem, we have been examining the movement, degradation, and persistence of petroleum in experimentally contaminated tundra soils. Further we have been examining changes in microbial populations following oil contamination of tundra soils. Other investigators have been examining changes in mycorhizzal associations, decompositonal rates, and soil chemical and physical properties in these soils. We have reported previously on initial changes that occur in oil composition (Sexstone and Atlas, 1977b). In this paper we examine changes in microbial populations and persistence of petroleum hydrocarbons in tundra soils after prolonged exposure. 


\section{MATERIALS AND METHODS}

\section{Sampling}

Experimental oil spill sites, established on polygonal tundra during summer, 1975 (Sexstone and Atlas, 1977a, 1977b) and on wet meadow tundra during summer, 1970 (Deneke et al., 1975), were used for this study. The polygonal tundra sites (listed in order of increasing moisture content) were a high center polygon top, a low center polygon rim, a low center polygon basin, and a low center polygon trough. Each microtopographically distinct soil studied included an area treated with $12 \mathrm{~lm}^{2}$ Prudhoe Bay crude oil, an area treated with $5 / \mathrm{m}^{2}$ Prudhoe Bay crude oil, and an untreated reference area. Samples for this study were collected on 1 July, and 25 August 1977, from the polygonal tundra soils, and on 17 July 1977, from the wet meadow tundra soils. Soil cores, $5 \mathrm{~cm}$ diameter, were cut into $0-2,2-4$, and $4-8 \mathrm{~cm}$ depth sections. Only single cores were used but duplicate samples were collected from each core. Samples were handled aseptically and maintained at $5{ }^{\circ} \mathrm{C}$ during processing. The $0 \mathrm{~cm}$ depth was considered as the soil surface after removal of the overlying vegetation layer.

\section{Enumeration of Microorganisms}

Samples from the centers of the soil cores were used for enumerating microbial populations. Viable plate counts were used to enumerate viable heterotrophs, viable fungal propagules, and viable oil utilizers. Details of the enumeration procedures have been described previously (Sexstone and Atlas, 1977b). Although only the results of mesophilic enumerations are reported in this paper, enumerations of psychrophilic microorganisms were also performed. To simplify presentation of the data the results are presented as ratios of seasonal mean populations in oil treated soils to seasonal mean populations in the reference soils. This ratio indicates differences in microbial populations resulting from exposure to oil. Ratios greater than 1 indicate enrichment, ratios less than 1 indicate inhibition.

\section{Analysis of Residual Oil}

Residual oil was recovered from the acidified soil core sections by solvent extraction using Soxhlet extractors (Sexstone and Atlas, 1977a). Additionally, artifically weathered crude oil was prepared by adding Prudhoe Bay crude oil to sterilized tundra soil in vitro and blowing sterile air over the soil for 96 hours before extraction. Recovered oil samples were weighed. Weights of solvent recovered oil were corrected by subtracting the weight of any material extracted from comparable reference soils. Selected samples were further analyzed by gas liquid and column chromatography. Column chromatographic analysis separated the oil into five fractions of structural hydrocarbon classes (Coleman et al., 1973; Horowitz and Atlas 1977). Gas chromatographic analyses were performed as previously described (Sexstone and Atlas 1977a) with the exception that $6 \mathrm{~m} \times 0.3 \mathrm{~cm}$ columns packed with $3 \%$ OV101 on 80-100 mesh Supelcoport were used. The ratio of resolved components to 
the total integrated area response was used as an index of biodegradation. Integration was delayed five minutes after injection to allow for separation of the solvent.

\section{RESULTS}

\section{Enumeration of microorganisms}

As shown by the ratios in Table 1, in situ exposure to oil resulted in changes in microbial population levels. Numbers of microorganisms were typically elevated in high center polygon top, and low center polygon rim soils after 26 months' exposure to Prudhoe Bay crude oil. In these soil types, greater increases in microbial numbers occurred in $12 / \mathrm{m}^{2}$ than in $5 / \mathrm{m}^{2}$ treated areas. Fungal propagules and oil utilizing microorganisms were in especially high relative numbers in the low center polygon rim soils. Numbers of heterotrophic microorganisms and fungal propagules were generally slightly higher in low center polygon basin soils than in reference soils. The increases were not as great in basin soils as in the rim or high center polygon top soils. Numbers of oil utilizing microorganisms, however, were often depressed in oil exposed basin soils. In low center polygon trough soils heterotrophic, fungal and oil utilizing microbial populations generally had similar or depressed numbers relative to the reference soils.

Oil analyses

Gravimetric analyses indicated that oil was still present in the experimentally treated soils 26 and 86 months after spillage (Table 2). Presence of petroleum hydrocarbons in solvent extracts was confirmed by gas liquid chromatography. Greatest concentrations of oil were found at the $0-2$ $\mathrm{cm}$ depth of all soils. Greater penetration to lower depths was observed in soils treated with $121 / \mathrm{m}^{2}$ than with $51 / \mathrm{m}^{2}$ oil. Recoverable oil was found

TABLE 1. Rates of numbers of microorganisms in oil exposed tundra soils to numbers of microorganisms in reference soils

\begin{tabular}{|c|c|c|c|c|c|c|c|c|c|}
\hline \multirow[b]{2}{*}{ Soil Type } & \multicolumn{3}{|c|}{ HETEROTROPHS } & \multicolumn{3}{|c|}{$\begin{array}{c}\text { FUNGAL } \\
\text { PROPAGULES }\end{array}$} & \multicolumn{3}{|c|}{$\begin{array}{c}\text { OIL } \\
\text { UTILIZERS } \\
\text { (Depth) }\end{array}$} \\
\hline & $\underline{0-2}$ & $2-4$ & $4-8$ & $\underline{0-2}$ & $2-4$ & 4-8 & $\underline{0-2}$ & $2-4$ & $4-8$ \\
\hline \multicolumn{10}{|c|}{ EXPOSURE: $5 \mathrm{l} / \mathrm{m}^{2} 26$ months } \\
\hline High Center Top & 7.0 & 21.0 & 2.0 & 8.0 & 0.2 & 0.5 & 13.0 & 13.0 & 4.0 \\
\hline Low Center Rim & 0.5 & 29.0 & 16.0 & 10.0 & 12.0 & 164.0 & 0.6 & 209.0 & 100.0 \\
\hline Low Center Basin & 5.0 & 7.0 & 0.8 & 3.0 & 3.0 & 3.0 & 1.0 & 9.0 & $<0.1$ \\
\hline Low Center Trough & 0.2 & 0.1 & 12.0 & 0.3 & 37.0 & 0.5 & 0.5 & 6.0 & 19.0 \\
\hline \multicolumn{10}{|c|}{ EXPOSURE: $12 \mathrm{l} / \mathrm{m}^{2} 26$ months } \\
\hline High Center Top & 51.0 & 110.0 & 22.0 & 18.0 & 1.0 & 3.0 & 11.0 & 3.0 & 4.0 \\
\hline Low Center Rim & 20.0 & 72.0 & 399.0 & 321.0 & 350.0 & 262.0 & 2500.0 & 49.0 & 17.0 \\
\hline Low Center Basin & 11.0 & 2.0 & 1.0 & 12.0 & 2.0 & 1.0 & 41.0 & 0.2 & 0.1 \\
\hline Low Center Trough & 0.6 & 0.1 & 2.0 & 1.0 & 15.0 & 0.9 & 3.0 & 0.9 & 0.8 \\
\hline
\end{tabular}


TABLE 2. Mean weight of recoverable oil (solvent extracted material) $\mathrm{mg} / \mathrm{g}$ wet weight soil

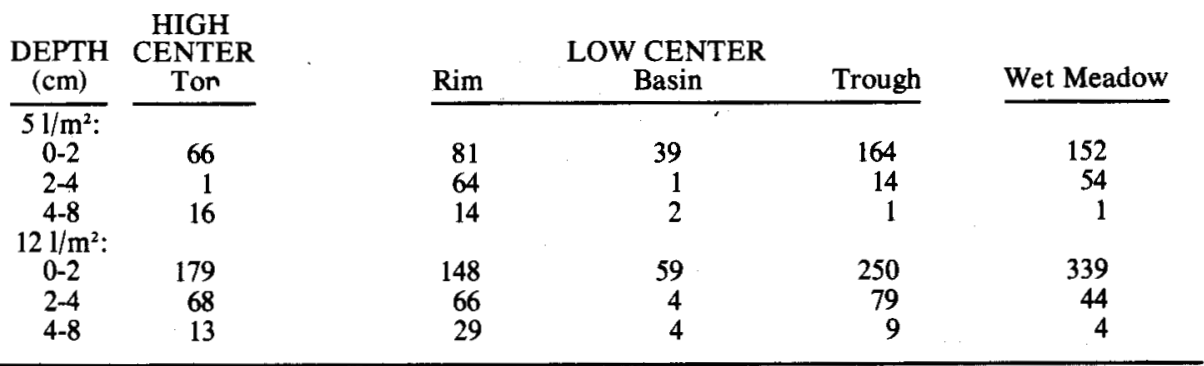

throughout the $0-8 \mathrm{~cm}$ soil core in well drained high center top and low center rim soils. In trough soils, most of the oil was recovered at the $0-4 \mathrm{~cm}$ depth. Oil in basin soils was generally restricted to the $0-2 \mathrm{~cm}$ depth. In wet meadow soils exposed to oil for 86 months, oil was found only in the upper 4 $\mathrm{cm}$ of soil with most of the recoverable oil at the $0-2 \mathrm{~cm}$ depth.

When compared with fresh or artifically weathered crude oil, oils exposed in situ in polygon tundra soils for 26 months showed a lower proportion of resolvable material (Table 3). Oil recovered from high center top, low center rim and low center trough soils had similar ratios of resolvable to total area. Oils exposed in basin soils showed a higher relative proportion of resolvable material than oil exposed in the other polygonal soils. Oils exposed in wet meadow tundra soils for 86 months showed a reduced proportion of resolvable compounds.

Column chromatographic analysis of residual oils extracted from the $0-2$ $\mathrm{cm}$ depth of soils treated at $121 / \mathrm{m}^{2}$ failed to show major shifts in the relative proportions of the five classes of hydrocarbons (Table 4). Oils recovered from high center top, low center rim and low center trough soils showed slight decreases in the relative proportion of the saturate fraction and slight increases in the polyaromatic and polar fraction compared to fresh and

TABLE 3. Percent of total integrated area that was resolved in gas liquid chromatographic analyses of recovered oils

Fresh crude oil

Artificially weathered oil $\ldots \ldots \ldots \ldots \ldots \ldots \ldots \ldots \ldots \ldots \ldots \ldots . \ldots \ldots$

Oil from high center top exposed for 26 months $\ldots \ldots \ldots \ldots \ldots \ldots \ldots . . .6$

Oil from low center rim exposed for 26 months $\ldots \ldots \ldots \ldots \ldots \ldots \ldots .8 .3$

Oil from low center basin exposed for 26 months $\ldots \ldots \ldots \ldots \ldots \ldots . . \ldots$

Oil from low center trough exposed for 26 months $\ldots \ldots \ldots \ldots \ldots \ldots . . \ldots .5$

Oil from wet meadow exposed for 86 months $\ldots \ldots \ldots \ldots \ldots \ldots \ldots$ 
TABLE 4. Column chromatographic analysis of residual oil showing relative percentages of the eluted classes

\begin{tabular}{|c|c|c|c|c|c|}
\hline & Saturate & $\begin{array}{c}\text { Mono- } \\
\text { aromatic }\end{array}$ & $\begin{array}{c}\mathrm{Di}- \\
\text { aromatic }\end{array}$ & $\begin{array}{c}\begin{array}{c}\text { Poly- } \\
\text { aromatic } \\
\text { Polar I }\end{array} \\
\end{array}$ & $\begin{array}{c}\text { Poly- } \\
\text { aromatic } \\
\text { Polar II }\end{array}$ \\
\hline Fresh crude oil & 50.6 & 12.2 & 9.0 & 23.5 & 4.7 \\
\hline Artificially weathered oil & 50.6 & 13.0 & 5.9 & 27.1 & 3.4 \\
\hline Oil from high center top" & 45.2 & 12.7 & 8.1 & 28.4 & 5.6 \\
\hline Oil from low center rim* & 48.6 & 12.4 & 6.2 & 28.9 & 3.8 \\
\hline Oil from low center basin* & 53.7 & 12.6 & 3.7 & 27.0 & 2.9 \\
\hline Oil from low center trough* & 47.2 & 14.7 & 8.9 & 25.2 & 4.0 \\
\hline Oil from wet meadow** & 47.8 & 5.3 & 8.7 & 32.3 & 5.8 \\
\hline
\end{tabular}

*exposed for 26 months

** exposed for 86 months

artifically weathered crude oil. Oil recovered from basin soils showed increases in the proportion of the saturate fraction and decreases in the diaromatic fraction. Oil recoverd from 86 month old wet meadow soils showed proportional decreases in the monoaromatic fraction and increases in the polyaromatic- polar fraction.

\section{DISCUSSION}

We have previously reported that mcrobial populations in tundra soils respond to the presence of crude oil (Sexstone and Atlas, 1977a, 1977b). Increases in microbial numbers in tundra soils due to the presence of crude oil have been reported by other workers (Jobson et al., 1973; Campbell et al., 1973; Parkinson et al., 1972; McFadden et al., 1977). Elevated microbial populations were still observable 26 months after spillage in this study. Population levels after 26 months' exposure to oil were approximately the same as had been found after 14 months' exposure. In trough soils the decreased ratio of microbial numbers in the upper $4 \mathrm{~cm}$ of the oil exposed soil to the reference soil may be due to toxicity resulting directly or indirectly from oil deposition. Oil initially floated above this soil due to high moisture content and standing water, but showed rapid penetration and localized areas of high oil concentration (pooling) one year after spillage due to very dry (drought) conditions. We have observed similar low ratios in wet meadow tundra soils associated with natural oil seepages (Sexstone and Atlas, 1978). This suggests that under certain conditions oil contamination can result in inhibition rather than stimulation of microbial populations in tundra soils. 
As previously reported, the penetration of oil appears to depend on the moisture and drainage characteristics of the soil (Sexstone and Atlas, 1977a). Sorption of oil to soil particles may also limit mobility of oil into tundra soils (Yong and Sethi, 1973). Oil remains at or near the soil surface. Pooling of oil was seen in some areas, especially in low center polygon trough soils. Compared to our previous results residual oil has not moved from where it was one year after spillage. Oil appears to have reached its maximum depth of penetration within one year after spillage.

There is evidence that the oil that persists in the upper soil layer is undergoing slow biodegradation. Due to the fact that these studies were conducted in an open system, it was not possible to quantitfy the actual rate of biodegradation by measuring weight loss of oil. Rather, evidence for biodegration is based on measuring compositonal changes in the recovered oil. The column chromatographic analyses showed only minor alterations in the biodegradation of hydrocarbon classes. This could indicate that no proportions had occurred or that degradation of classes of hydrocarbons had occurred at similar relative rates. A similar lack of change in class composition has been observed previously in temperate soils (Raymond, et al., 1976) and in Arctic aquatic ecosystems (Horowitz and Atlas, 1977) where biodegradation was known to occur. The minor shifts in relative class composition suggest that complex aromatic components are more resistant to to biodegradation that saturate or monoaromatic compounds. The minor changes in class composition also suggest that biodegradation in basin soils was different than in other tundra soils. Our results are quite different than the major changes in hydrocarbon class composition found after incubation of microorganisms obtained from enrichments with northern Canadian soils and Prudhoe Bay crude oil (Westlake et al., 1974). We believe, in the cold nutrient limited soils that we studied, biodegradation occurs slowly with no major preferential utilization of classes of hydrocarbons during the period of exposure. Fertilizers were not added in our study as it was our purpose to study the natural fate of spilled oil. Fertilizer applications could have resulted in more extensive degradation and compositional changes.

The lack of major changes in the proportions of hydrocarbon classes does not indicate that some individual components were not preferentially degraded. We have previously used changes in the pristane to heptadecane ratio as an indicator of biodegradation. In this study we used the ratio of resolved to total integrated area in gas liquid chromatographic and analysis as an index of biodegradation. Major changes in this ratio were found for exposed oils. The change in this ratio could not be due to evaporative weathering processes as shown by comparison to the artifically weathered oil. The greatest change in this ratio was found for the oil recovered after 86 months' exposure. The least change as shown by this biodegradation index occurred in low center polygon basin soils. We note that either slower rates of biodegradation of resolvable components or more rapid degradation of unresolved compounds in the gas chromatographic envelope in basin soils could give this result. The column chromatographic analysis of oil recovered 
from basin soils would support the latter hypothesis. The observed ratios of resolved to total components clearly shows that some compounds are being preferentially removed from the oil.

We believe that changes in relative proportions of components in crude oil can be used as a biodegradation index, and as stated previously the degradation rates indicate that petroleum hydrocarbons will persist near the surface layer of oil contaminated tundra soils for prolonged periods. We have not yet investigated the factors that control and restrict the rates of degradation. In tundra soils it is the long term fate and effects of oil that must be of concern.

\section{ACKNOWLEDGEMENTS}

This work was supported by the Energy Resources Development Administration. We thank Dr. O. K. Miller, Dr. K. Everett, Dr. A. E. Linkins, and Mr. R. Antibus for their cooperation in performing this study.

\section{REFERENCES}

CAMPBELI, W. B., R. W. HARRIS and R. E. BENOIT. 1973. Response of Alaskan tundra microflora to crude oil spill. Proc. Symposium on the Impact of Oil Resources Development on Northern Plant Communities. Institute of Arctic Biology Occasional Publication No. 1. University of Alaska, Fairbanks. p. 53-62.

COLEMAN, H. J., J. E. DOOLEY, D. E. HIRSH, and C. J. THOMPSON. 1973. Compositional studies of a high boiling $370-535^{\circ} \mathrm{C}$ distillate from Prudhoe Bay, Alaska, crude oil. Analytical Chemistry. 45:1724-1737.

DENEKE, F. J., B. H. McCOWN, P. I. COYNE, W. RICKARD and J. BROWN. 1975. USA CRREL Research in Alaska, 1970-1074. CRREL Report 346. Cold Regions Research and Engineering Laboratory. Hanover, NH.

HOROWITZ, A. and R. M. ATLAS. 1977. Continuous open flow-through system as a model for oil degradation in the Arctic Ocean. Applied and Environmental Microbiology. 27:166-171.

JOBSON, A., N. M. McLAUGHLIN, F. D. COOK, and D. W. S. WESTLAKE. 1973. Effects of amendments on the microbial utilization of oil applied to soil. Applied Microbiology. 27:166-171.

McFADDEN, T., T. JENKINS, C. COLLINS, L. JOHNSON, B. McCOWN, and E. SPARROW. 1977. Fate and effects of crude oil spilled on permafrost terrain. CRREL Report SR-77-44. Cold Regions Research and Engineering Laboratory. Hanover, N.H.

PARKINSON, D. 1972. Technical report to environmntal-social program, nothern pipelines. Canadian Department of Indian and Northern Affairs.

RAYMOND, R. L., J. O. HUDSON, and V. W. JAMISON. 1976. Oil degradation in soil. Applied and Environmental Microbiology. 31:522-535.

SEXSTONE, A., and R. M. ATLAS. 1977a. Mobility and biodegradability of crude oil in Arctic tundra soils. Developments in Industrial Microbiology. 18:673-684.

SEXSTONE, A. and R. M. ATLAS. 1977b. Response of microbial populations in Arctic tundra soils to crude oil. Canadian Journal of Microbiology. 23:1327-1333.

SEXSTONE, A. and R. M. ATLAS. 1978. Persistence of oil in tundra soils. Developments in Industrial Microbiology. 19: 507-516.

WESTLAKE, D. W. S., A. JOBSON, R. PHILLIPPE and F. D. COOK. 1974. Biodegradability and crude oil composition. Canadian Journal of Microbiology. 20:915-928.

YONG, R. N. and A. J. SETHI. 1973. Basic concepts in oil-soil interaction and preliminary results. Soil Mechanics Laboratory Report No. OS-NR-1. McGill University, Montreal, Quebec. 